\title{
List of figures, tables and appendices
}

\section{Figures}

Figure 1.1 Map of the territorial borders in the area between Aachen and Liège in the eighteenth century

Figure 1.2 Bronze statuette representing a cloth shearer adorning the top of the Weberbrunnen fountain in Monschau

Figure 1.3 Cloth shearers in a workshop. Engraving by J.G. van Vliet, Leiden, 1635

Figure 1.4 Cloth shearers working with a crook or mailloche in their right hands. Engraving, France, seventeenth century

Figure 1.5 Map of the centres of cloth production in Northwestern Europe and years of strike actions between 1588 and 1830

Figure 2.1 Julius Bruhns (Hamburg 1860-Offenbach 1927)

Figure 2.2 Interior of a cigar factory in Havana, Cuba, c. 1903

Figure 2.3 Friedrich Wilhelm Fritsche (Leipzig 1825-Philadelphia 1905)

Figure 3.1 Carpenters at the construction of the Paleis voor Volksvlijt (Palace of People's Industry), Amsterdam, c. 1862

Figure 3.2 Boys labour in the Senefelder printing works, Amsterdam, c. 1900

Figure 4.1 Cutting glass-cylinders in a Belgian window-glass factory

Figure 4.2 Interior of the window-glass factory Verreries du Centre in Jumet, Belgium, date unknown $\quad 140$

Figure 4.3 Banner of L'Union Verrière Belge, $1894 \quad 149$

Figure 4.4 Glass-blowers and -cutters on strike, date unknown $\quad 150$

Figure 4.5 The main operations of diamond processing: splitting, cutting, polishing, c. 1880

Figure 6.1 Postcard issued by the German miners' union Alte Verband, date unknown

Figure 6.2 Map of the sub-districts of the South-Limburg mining region and the location of the mines

Figure 6.3 Membership development of смв and АNMB, 19071930 (31 December)

Figure 6.4 By-laws of the Christelijke Mijnwerkersbond, 1914 
Figure 7.1 Film poster of Bread \& Roses, the film about Justice for Janitors (J4J) in Los Angeles by Ken Loach, produced by Rebecca O’Brien, and written by Paul Laverty (2000)

Figure 7.2 Downtown rally by Justice for Janitors in Los Angeles, 1990

Figure 7.3 Meeting of the 'Cleaners' Parliament' in the Amsterdam Town Hall, 12 December 2009

Figure 7.4 March by some 400 cleaners during a sit-in at Utrecht Central Station, 16 March 2010

Tables

Table 1.1

Reported meetings and strikes of cloth shearers in Amsterdam and Leiden, seventeenth-eighteenth centuries

Table 1.2 Number of cloth shearers in industrial centres in the Meuse-Rhine region, around 1800

Table 1.3 Shearers' strikes in Sedan and in the Meuse-Rhine borderlands in the eighteenth century

Table 3.1 Membership of the Amsterdam carpenters' unions Concordia Inter Nos (1868-1893) and Door Eendracht Verbetering (1885-1893)

Table 3.2 Place of birth of board members and militants active in unions in the building trades and construction workers in the SD League not known as union members, 1873-1894

Table 3.3 Year of birth of board members and militants active in unions in the building trades and construction workers in the sD League not known as union members, 1873-1894

Table 3.4 Year of arrival of board members and militants born outside Amsterdam active in the socialist unions in the building trades, and of construction workers in the sD League not known as union members, 1885-1894

Table 3.5 Province of birth of board members and militants born outside Amsterdam active in the socialist unions in the building trades, and of construction workers in the sD League not known as union members, 1885-1894 
Table 3.6 Membership of the Amsterdam branch of the Algemeene Nederlandsche Typografen Bond, 1866-1869 and 1889-1895

Table 3.7 Year of birth of board members of the Amsterdam branch of the Algemeene Nederlandse Typographen Bond and in the typographical societies De Nederlandsche Drukpers and Voorzorg en Genoegen (affiliated to the ANWV), before and after 1889

Table 3.8 Age structure of active members of the Social Democratic League and the ANwv before and after 1885 (percentages)

Table 6.1 Membership of the смв in 1915 (31 December) and the ANMB in 1916 (31 December), and gross monthly membership growth of the ANMB in 1913 in the subdistricts of the Limburg mining district, compared to the number of miners living there (density) in 1909 211

Table 6.2 Membership and net membership growth of the ANMB in the sub-districts of the Limburg mining district, 1 January-1 April 1917 220

Table 6.3 Membership growth of the смв (net) and the АNмв (gross) in the towns and villages in sub-districts of the Limburg mining district, 1918

Table 7.1 The five largest cleaning companies in the Netherlands, 2011

Appendices

Appendix 1.1 Regulations against shearers' collective actions

Appendix 6.1 Map of dwelling places of miners mentioned in Chapter 6

Appendix 6.2 Membership of CMB (1915) and ANMB (1916), gross monthly growth of ANMB (1913), miners living in the Limburg mining district (1909), and workmen's train fares issued in 1911

Appendix 7.1 Meetings, pickets, and manifestations in preparation and during the 2010 strike 